\title{
Gastrointestinal Stromal Tumors - A Case Series - Our Experience Over Four Years in a Tertiary Care Medical College Hospital
}

\author{
Sreeramulu PN*, Prakash Dave, Vikranth SN, Karthik Hareen TVK, Suma S \\ Department of General Surgery, Sri Devraj Urs Medical College, India \\ Submission: July 10, 2017; Published: July 26, 2017 \\ *Corresponding author: Sreeramulu PN, Department of General Surgery, Sri Devraj Urs Medical College, , India, \\ Email: karthikhareen08@gmail.com
}

\begin{abstract}
Background: Gastrointestinal stromal tumors (GIST) are mesenchymal tumors and account for 3\% of all gastrointestinal malignancies. They are unpredictable, rare, enigmatic and display aggressive behavior1. They express tyrosine kinase (KIT) and commonly involve small gut and stomach (rarely esophagus, mesentery and colon). A series of 11 cases of GIST managed in a teaching hospital attached to a medical college over 4 years is presented.
\end{abstract}

Methods: Medical records of the 11 cases of GIST managed during January 2013 through December 2016 were reviewed for patient demographics, clinical presentation, investigation, sites, treatment, histology, immunohistochemistry and Imatinib therapy. Follow up for recurrence over the period ranging from 6 months to 4 years was done.

Results: GIST was common in men. Age ranged 28 to 75 years. Sites involved were--small bowel in 5, stomach in 2, mesentery in 2, rectum and greater omentum 1 each. Symptoms ranged from abdominal pain, mass, upper /lower gastrointestinal bleeding, small bowel obstruction. Surgery was the mainstay of the treatment. All were positive for tyrosine kinase. One case was non respectable and another showed metastasis to the mesenteric lymph nodes, which is uncommon. All received Imatinib post operatively. Recurrence was seen in one patient with small bowel GIST at 2 years.

Conclusions: GIST are uncommon with varied presentations and may be aggressive and can recur. GIST tumors elaborate tyrosine kinase, hence KIT receptor inhibitor Imatinib was useful in all, non respectable \& recurrent tumors. Tyrosine kinase inhibitor has thus drastically changed the diagnosis and management of these tumors.

Keywords: Gastrointestinal Stromal Tumors; Imatinib Desolate; Tyrosine Kinase

Abbreviations: PDGFRA: Platelet-derived growth factor receptor alpha; IHC: Immunohistochemistry; GIST: Gastrointestinal Stromal tumor

\section{Introduction}

Gastrointestinal stromal tumor (GIST) are mesenchymal tumors arising from gastrointestinal tract, mesentery, or omentum. They account for up to $3 \%$ of gastrointestinal malignancies [1]. In frequency these tumors rank distant third after adenocarcinoma and lymphomas of gastrointestinal tract tumors histologically. GIST arises from the interstitial cells of Cajal. These are complex group of cell network which are the pace makers of the gut and initiate peristalsis [2]. Age incidence for GISTs is usually in adults between 40 and 70 and can be benign or malignant [3]. These tumors most commonly occur in the stomach and the small bowel. Clinical presentation is variable according to the site of tumor and the size. The most common symptoms encountered are abdominal mass, weight loss, gastrointestinal bleeding, anemia, pain abdomen, small or large bowel obstructive symptoms.

GIST rank third in frequency after adenocarcinoma and lymphomas. They form 1-2 \% among the histologic types of gastrointestinal tract tumors. 900 new cases are diagnosed in UK every year. Expression of tumor marker receptor tyrosine kinase KIT by GIST cells has revolutionized the diagnosis and management of GIST during the last 15 years. Discovery of Imatinib Maculate, a specific tyrosine kinase inhibitor, resulted in significantly improved survival (above $80 \%$ ). We present a case series of 11 cases of Gastrointestinal Stromal Tumors managed in a tertiary care hospital attached with this medical college, over a period of 4 years (January 2013 through December 2016). 


\section{Materials and Methods}

This was a retrospective observational study. Medical records of the 11 cases of GIST managed during the period from January 2013 through December 2016 were reviewed for patient demographics, clinical presentation, investigation results (upper gastrointestinal endoscopy and colonoscopy, radiologic imaging). The tumor characteristics locations of the tumors, type of surgical resections, histopathology, immunohistochemistry analysis, Imatinib Maculate therapy post operatively or as palliation (even where resection surgery not contemplated), treatment outcome were noted and studied. Follow up for recurrence over a period ranging from 6 months to 4 years were also studied. The prognostic factors-size, mitotic index \& metastasis were observed and classified using Fletcher's classification.

\section{Results}

Of the 11 patients, men accounted ( $n=7,63.7 \%)$, women $(n=4,36.3)$. Age range was 28 to 75 years, mean age 57.7 years, median age 61 years. Symptoms ranged from abdominal pain, epigastric discomfort, mass, upper /lower gastrointestinal bleeding, rectal bleeding, anemia, weight loss and small bowel obstruction. Sites involved were small bowel in $(n=5,45.45 \%)$, stomach in $(n=2,18.18 \%)$, mesentery in $(n=2,18.18 \%)$, rectum and greater omentum in $(n=1,9.09 \%)$ each.

Gastric wedge resection done in 2 cases, small bowel resection anastomosis done in 5 cases, excision of mesenteric GIST with adjacent jejunum in 2 cases. Anterior resection in 1 case of rectal GIST .One (n=1, 9.09\%) case of recurrent mesenteric and greater mental GIST was non respectable. One case of mesenteric GIST ( $\mathrm{n}=1,9.09 \%)$ had a respectable tumor but postoperative histopathology reported metastasis to the mesenteric lymph nodes. Recurrence seen in one patient $(n=1$, $9.09 \%$ ) with small bowel GIST at 2 years. The non respectable case of recurrent GIST received Imatinib. One case (n=1, 9.09\%) received Sunitinib.

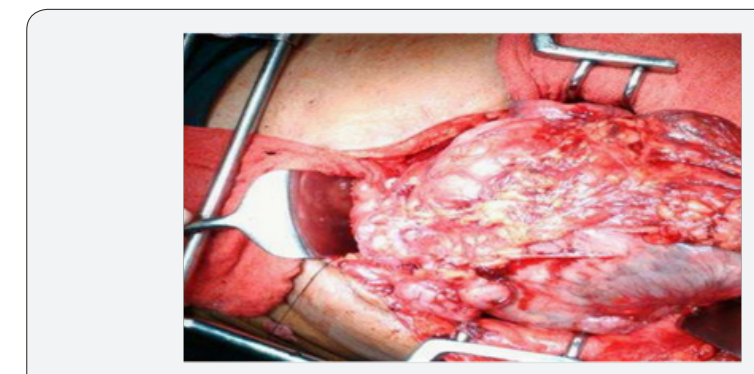

Figure 1: Mesenteric lymph nodes

The tumor sizes varied from $2.5 \mathrm{~cm}$ to $22 \mathrm{~cm}$. Tumor histology showed spindle shaped cells with necrosis and hemorrhage in all cases. Mitotic index varied from $0 / 50 \mathrm{HPF}$ to $>10 / 10 \mathrm{HPF}$. One case $(n=1,9.09 \%)$ of jejunal mesenteric GIST showed metastatic deposits in 12 out of 24 mesenteric lymph nodes (Figure 1). Immunohistochemistry (IHC) for CD117/C kit was positive in all cases. Recurrence was seen in one case $(n=1,9.09 \%)$ of small bowel GIST at 2 years post treatment. One case $(n=1,9.09 \%)$ was lost to follow up and one case died of acute myocardial infarction 7 months post treatment [4] (Table 1).

Table 1: Acute myocardial infarction 7 months post treatment.

\begin{tabular}{|c|c|c|c|c|c|c|c|c|c|}
\hline $\begin{array}{l}\text { Sr } \\
\text { No. }\end{array}$ & $\begin{array}{l}\text { Age / } \\
\text { sex }\end{array}$ & $\begin{array}{l}\text { Location of } \\
\text { the GIST }\end{array}$ & $\begin{array}{l}\text { Primary } \\
\text { symptom }\end{array}$ & $\begin{array}{l}\text { Size of the } \\
\text { tumour }\end{array}$ & $\begin{array}{l}\text { Primary } \\
\text { treatment }\end{array}$ & $\begin{array}{c}\text { IHC } \\
\text { Analysis }\end{array}$ & histopatholoy & $\begin{array}{l}\text { Post op } \\
\text { treatment } \\
\text { (imatinib/ } \\
\text { sunitinib }\end{array}$ & $\begin{array}{c}\text { FU / } \\
\text { recurrence } \\
\text { \& time } \\
\text { period }\end{array}$ \\
\hline 1 & $66 / \mathrm{M}$ & Small gut & $\begin{array}{l}\text { Small bowel } \\
\text { obstruction }\end{array}$ & $10 \mathrm{cms}$ & Surgery & $\begin{array}{l}\text { CD117/Ckt } \\
\text { positive }\end{array}$ & $\begin{array}{l}\text { Spindle cells } \\
8-10 / \mathrm{HPF}\end{array}$ & YES & $\begin{array}{l}\text { YES,2 yrs } \\
\text { post op }\end{array}$ \\
\hline 2 & $75 / M$ & $\begin{array}{l}\text { Body of } \\
\text { stomach }\end{array}$ & $\begin{array}{l}\text { Upper G I } \\
\text { bleeding }\end{array}$ & $5 \times 3.5 \times 3.5$ & Surgery & $\begin{array}{l}\text { CD117/Ckt } \\
\text { positive }\end{array}$ & $\begin{array}{l}\text { Spindle cells } \\
<5 / 50 \mathrm{HPF}\end{array}$ & YES & $\begin{array}{l}\text { No, at } 2 y r s \\
7 \text { months }\end{array}$ \\
\hline 3 & $42 / \mathrm{F}$ & Small gut & Lower abd pain & $4.8 \mathrm{cms}$ & Surgery & $\begin{array}{l}\text { CD117/Ckt } \\
\text { positive }\end{array}$ & $\begin{array}{l}\text { Spindle shaped } \\
\text { cells, } 9 / 50 \mathrm{HPF}\end{array}$ & YES & $\begin{array}{l}\text { No } 18 \\
\text { months }\end{array}$ \\
\hline 4 & $61 / F$ & Rectum & $\begin{array}{l}\text { Lower GI } \\
\text { bleeding }\end{array}$ & $8 \mathrm{cms}$ & Surgery & $\begin{array}{l}\text { CD117/Ckt } \\
\text { positive }\end{array}$ & $\begin{array}{l}\text { Spindle cells } \\
5 / 50 \mathrm{HPF} \\
\text { mitotic index }\end{array}$ & YES & $\begin{array}{c}\text { No, } 1 \\
\text { yr post } \\
\text { treatment }\end{array}$ \\
\hline 5 & $38 / \mathrm{M}$ & Jejunum & $\begin{array}{l}\text { Abd pain, rectal } \\
\text { bleeding }\end{array}$ & $2.5 \mathrm{cms}$ & Surgery & $\begin{array}{l}\text { CD117/Ckit } \\
\text { positive }\end{array}$ & $\begin{array}{c}\text { Spindle } \\
\text { cells },<1 / 50 \text { HPF }\end{array}$ & YES & $\begin{array}{l}\text { Lost to } \\
\text { follow up }\end{array}$ \\
\hline 6 & $80 / \mathrm{M}$ & Stomach & $\begin{array}{l}\text { Epigastric } \\
\text { discomfort }\end{array}$ & $3 \mathrm{cms}$ & Surgery & $\begin{array}{l}\text { CD117/Ckit } \\
\text { positive }\end{array}$ & $\begin{array}{l}\text { Severe nuclear } \\
\text { atypia,6/50 HPF } \\
\text { Mitotic index }\end{array}$ & YES & $\begin{array}{c}\text { No, till } 1 \\
\text { yr post } \\
\text { treatment, } \\
\text { died of ac } \\
\text { myocardial } \\
\text { infarction }\end{array}$ \\
\hline 7 & $38 / F$ & Mesentery & Abd discomfort & $\begin{array}{c}20 \times 18 \times 16 \\
\mathrm{cms}\end{array}$ & Surgery & $\begin{array}{l}\text { CD117/Ckit } \\
\text { positive }\end{array}$ & $\begin{array}{c}\text { Spindle } \\
\text { cells, twisted } \\
\text { nuclei,7/50HPF }\end{array}$ & YES & $\begin{array}{l}\text { No, } 30 \\
\text { months } \\
\text { post } \\
\text { treatment }\end{array}$ \\
\hline
\end{tabular}




\section{Open Access Journal of Surgery}

\begin{tabular}{|c|c|c|c|c|c|c|c|c|c|}
\hline 8 & $65 / M$ & $\begin{array}{l}\text { Greater } \\
\text { omentum }\end{array}$ & Abd lump & $20 \times 17 \times 6$ & Surgery & $\begin{array}{l}\text { CD117/Ckit } \\
\text { positive }\end{array}$ & $\begin{array}{l}\text { Mixed spindle } \\
\text { and epitheloid } \\
\text { cells, } 2 / 50 \mathrm{HPF}\end{array}$ & YES & $\begin{array}{c}\text { No, } 6 \\
\text { months } \\
\text { post } \\
\text { treatment }\end{array}$ \\
\hline 9 & $28 / F$ & Small gut & Abd pain & $13 \times 10 \times 9$ & Surgery & $\begin{array}{l}\text { CD117/Ckit } \\
\text { positive }\end{array}$ & $\begin{array}{l}\text { Mixed spindle } \\
\text { and epitheloid } \\
\text { cells5/50 HPF }\end{array}$ & YES & $\begin{array}{c}\text { No, } 3 \\
\text { yrs post } \\
\text { treatment }\end{array}$ \\
\hline 10 & $70 / \mathrm{M}$ & jejunum & $\begin{array}{c}\text { Rt IF ,Rt } \\
\text { lumbar,umbilical } \\
\text { areas mass }\end{array}$ & $10 \times 8 \times 6 \mathrm{cms}$ & Surgery & $\begin{array}{l}\text { CD117/Ckit } \\
\text { positive }\end{array}$ & $\begin{array}{l}\text { Spindle cells, } \\
\text { 7/50 HPF }\end{array}$ & YES & $\begin{array}{c}\text { No, } 4 \\
\text { months } \\
\text { post } \\
\text { treatment }\end{array}$ \\
\hline 11 & $65 / M$ & $\begin{array}{l}\text { Jejunal } \\
\text { mesentery }\end{array}$ & $\begin{array}{l}\text { Recurrent Large } \\
\text { abd mass }\end{array}$ & $\begin{array}{c}22 \times 20 \times 15 \\
\mathrm{cms}\end{array}$ & Imatinib & $\begin{array}{l}\text { CD117/Ckit } \\
\text { positive }\end{array}$ & $\begin{array}{c}\text { Spindle cells in } \\
\text { whorls, }>10 / 10 \\
\text { HPF mitotic } \\
\text { index, malignant } \\
\text { GIST, high grade }\end{array}$ & YES & $\begin{array}{c}\text { Metastatic } \\
\text { disease, } \\
\text { surviving } \\
6 \text { months } \\
\text { post } \\
\text { treatment }\end{array}$ \\
\hline
\end{tabular}

\section{Discussion}

GISTs are the commonest mesenchymal tumors of the gastrointestinal tract. Apart from stomach, small gut, they may originate in the large gut, esophagus, mesentery and omentum. The American Joint Committee on Cancer (AJCC) Cancer Staging Manual lists the following approximate distributions-Stomach (60\%),Small intestine (30\%), Rectum (3\%),Colon (1-2\%),Esophagus (<1\%),Omentum /mesentery (rare). Infrequently, GIST may arise in the appendix, gallbladder, pancreas, retro peritoneum, and tissues around pelvic organs. GISTs were found commonly in adult males, between ages 28 75 years (40 and 70 years as per published literature [3] and can be benign or malignant [2]. Presenting complaints depended on the site of the GIST. Small gut GIST presented with small gut obstruction, abdominal lump. Gastric GIST presented with epigastric discomfort, upper gastrointestinal bleeding. Rectal GIST presented with rectal bleeding. Mesenteric /omental GIST reported with abdominal mass, anemia.

The abdominal radiograph (straight, erect) showed features of small /large gut obstruction. Ultrasound, CT scan, MRI showed the site, size of the tumors and the adjacent organs (liver, lymph nodes for involvement). Upper gastrointestinal endoscopy and colonoscopy showed wall irregularity and thickening in gastric and colonic/rectal GIST respectively. All patients required surgery. One case of greater omental GIST was un resectable as it involved inferior vena cava, aorta, left kidney and left colon. 20 to $25 \%$ of gastric and 40 to $50 \%$ of small gut GIST exhibit aggressive behavior [5]. Metastatic GIST is found in $10 \%$ to $25 \%$ of patients [5,6]. Monogenic mutations are detected in $85 \%$ of GIST in either KIT or PDGFRA (platelet-derived growth factor receptor alpha) tyrosine kinase receptors [7] GIST pathogenesis is the result of activation of either of these tyrosine kinase receptors [7,2]. Histologically GIST is composed of the following
[8] Spindle cells (70\%), Epithelioid cells (20\%), Mixed spindle and epithelioid cells (10\%) [7].

All received Imatinib post operatively. Imatinib Mesylate (IM) is tyrosine kinase receptor inhibitor and is the hallmark of treatment of GISTs. Imatinib has exhibited response rate in $>80 \%$ cases and enhanced the survival to $>5 y$ rs in more than $50 \%$ of unrespectable or metastatic GISTs. The dosage of Imatinib should be modified in hepatic or renal impairment. Common toxic effects of IM are nausea, vomiting, skin rash, and bone marrow depression and in some patients with tumor hemorrhage has been noted Predictors of aggressive behavior in GISTs have been proposed as --Very low risk-size $<2 \mathrm{~cm}$, mitotic index $<5 / 50 \mathrm{HPF}$, low risk- $2-5 \mathrm{~cm}$, mitotic index $<5 / 50 \mathrm{HPF}$, intermediate risk- $<5 \mathrm{~cm}, 6-10 / 50 \mathrm{HPF}$ mitotic index or $5-10 \mathrm{~cm}$ ,6-10 /50 HPF, high risk- $>5 \mathrm{~cm}$ and $>5 / 50 \mathrm{HPF}$ or $>10 \mathrm{~cm} \&$ any mitotic rate or any size and $>10 / 50 \mathrm{HPF}$.

Predictors for recurrence are-- tumor size $>5 \mathrm{~cm}$, high grade, tumor rupture, small bowel origin [5,8,9] (From)Every effort should be made to avoid tumor rupture during surgery as this drastically reduces survival [10]. A study conducted by Pierie and De Matteoshowed high recurrence in GIST with high risk features. 5-year survival was $42 \%$ when complete resection was done as compared to $9 \%$ if the excision was incomplete [8]

We had used Imatinib in the recurrent unrespectable mesenteric and omental GIST and all the operated cases postoperatively. Indications of preoperative Imatinib are: large localized, resectable tumors, impending hemorrhage or rupture, poorly localized small tumors that are difficult to resect, nonmetastatic but un resectablelocalized GISTs and If tumor free resection margins not achievable. Preoperative Imatinib may be continued until maximal response is achieved. Response should be assessed after 8 weeks of initiation [4]. In our series one case of recurrence of small bowel GIST and another case of 
unresectable recurrent mesenteric GIST received Imatinib for 12 weeks and showed good palliation and regression of the tumors. A very peculiar feature of this series was that in one patient of jejunal mesenteric GIST whose tumor was resected but showed metastasis in the mesenteric lymph nodes (12 out of 24 lymph nodes were positive), a very unusual feature of metastatic GIST.

\section{Conclusion}

GISTS are unpredictable mesenchymal tumors. Common sites are stomach and small gut. Mesenteric and omental GIST are rare. Surgery and Imatinib Mesylate therapy are the options available to the surgeon. Imatinib along with complete en bloc surgical excision with a clear margin and unbreached pseudo capsule is the standard initial management for all localized resectable GISTs \&help in improving long term survival. For gastric GIST a wedge resection or resection anastomosis for intestine is adequate. En-bloc resection should be considered if neighboring structures are involved but are removable.

Neoadjuvant Imatinib can be considered for downsizing of initially un respectable tumor thus allowing adequate subsequent resection with reduced surgical morbidity. Adjuvant Imatinib is indicated in patients at higher risk of recurrence. In metastatic or recurrent GIST, the primary treatment would be Imatinib. Sumatinib can be used for resistant or intolerant cases. A multidisciplinary approach and close collaboration between a medical oncologist, gastroenterologist, radiologist, oncopathologist and principally the surgeon are mandatory to provide GIST patients with the best available treatment.

\section{References}

1. Kindblom LG, Remotti H E, Aldenborg F, Meis-Kindblom JM (1998) Gastrointestinal pacemaker cell tumor (GIPACT): gastrointestinal stromal tumors show phenotypic characteristics of the interstitial cells of Cajal. Am J Pathol 152(2): 1259- 1269.

2. Hirota S, Isozaki K, Moriyama Y (1998) Gain-of-function mutations of c-kit in human gastrointestinal stromal tumors. Science 279(5350): 577-580.

3. Edge SB, Byrd DR, Compton CC (2010) Gastrointestinal stromal tumor. In: eds.: AJCC Cancer Staging Manual. Usa NY: Springer pp .175-80.

4. Christopher B, Tan, Wanqing Zhi (2012) Gastrointestinal stromal tumors: a review of case reports, diagnosis, treatment, and future directions. ISRN Gastroenterology.

5. Joensuu H (2006) Gastrointestinal stromal tumor (GIST). Ann Oncol 25(3): 21-26.

6. DeMatteo RP, Lewis JJ, Leung D (2000) Two hundred gastrointestinal stromal tumors: recurrence patterns and prognostic factors for survival. Ann Surg 231 (1): 51-58.

7. Corless CL, McGreevey L, Haley A, Town A (2002) Heinrich MC. KIT mutations are common in incidental gastrointestinal stromal tumors one centimeter or less in size. Am J Pathol 160(5): 1567-1572.

8. Heinrich MC, Blanke CD, Druker BJ, Corless CL (2002) Inhibition of KIT tyrosine kinase activity: a novel molecular approach to the treatment of KIT-positive malignancies. J Clin Oncol 20(6): 1692-1703.

9. Fletcher (2002) Human Pathology 33(5): 459-465.

10. Langer C, Gunawan B, Schuler P (2003) Prognostic Factors influencing surgical management and outcome of gastrointestinal stromal tumors. British Journal of Surgery 90 (3): 332-339.

\section{Your next submission with Juniper Publishers} will reach you the below assets

- Quality Editorial service

- Swift Peer Review

- Reprints availability

- E-prints Service

- Manuscript Podcast for convenient understanding

- Global attainment for your research

- Manuscript accessibility in different formats

( Pdf, E-pub, Full Text, Audio)

- Unceasing customer service

Track the below URL for one-step submission https://juniperpublishers.com/online-submission.php 